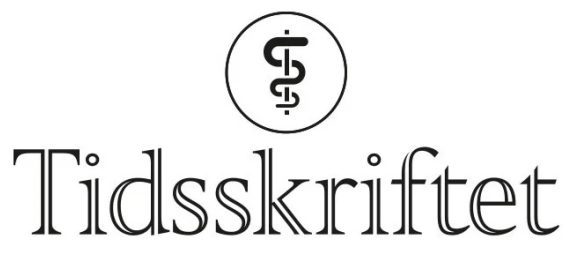

DEN NORSKE LEGEFORENING

\title{
Trening kan redusere grad av restenose
}

NYHETER

PETER S. MUNK

Email:munk@lyse.net

\section{ALF INGE LARSEN}

Stavanger universitetssjukehus

\section{Trening etter stentimplantasjon kan redusere grad av} restenose hos pasienter med stabil angina pectoris.

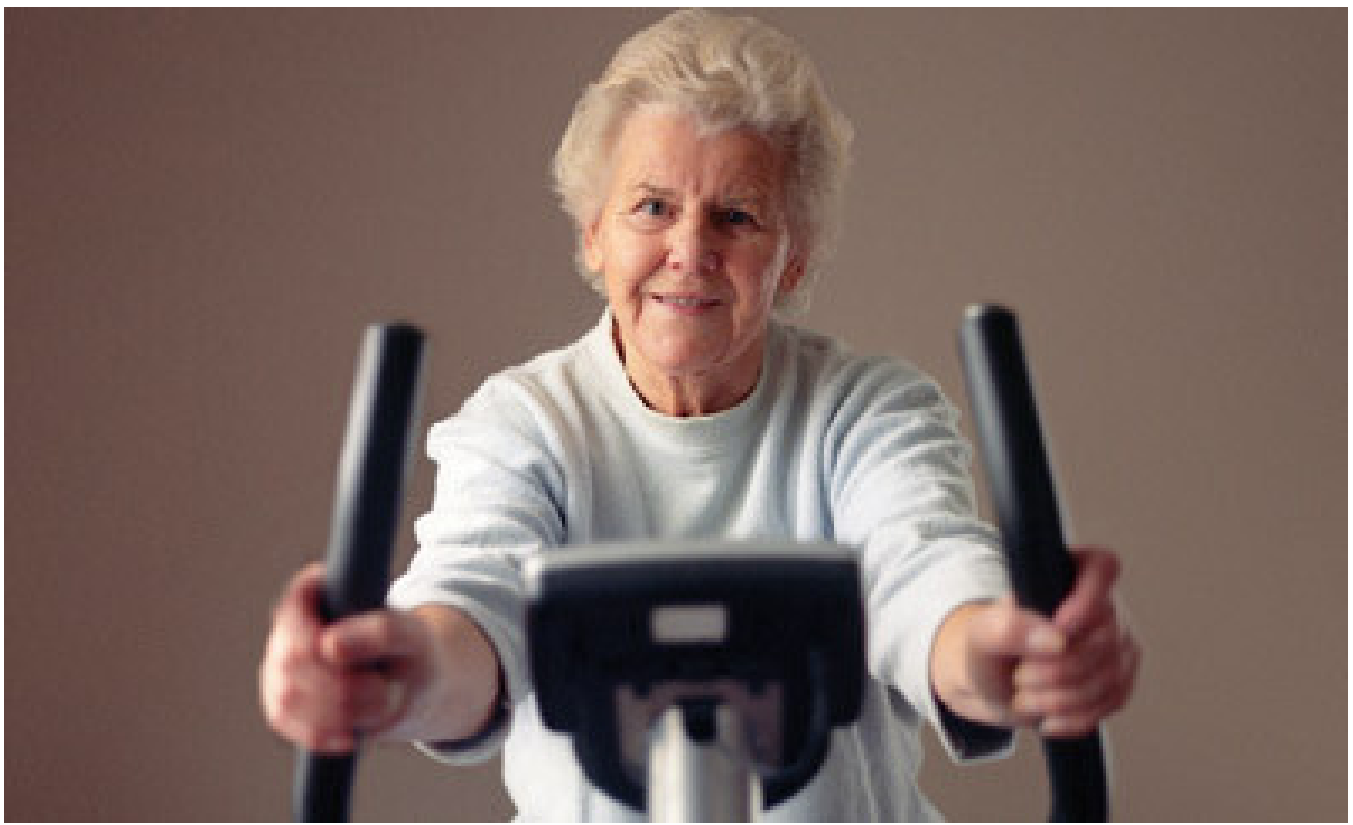

Illustrasjonsfoto @ Science Photo Library/GV-Press/NordicPhotos

Høyintensitetsintervalltrening reduserte grad av restenose hos pasienter som hadde gjennomgått utblokking med stentimplantasjon i koronarkar. Dette er konklusjonen i en prospektiv randomisert og kontrollert studie, der 40 pasienter ble fulgt opp i et halvt år ved Stavanger universitetssjukehus (1). 
Pasientene hadde angina pectoris og ble behandlet med utblokking og stenting.

Halvparten ble randomisert til organisert trening i en time tre ganger i uken, mens den andre halvparten kun fikk råd om å være fysisk aktiv. Treningen besto av

høyintensitetsintervaller på fire ganger fire minutter med sykling eller løping med $90 \%$ av makspuls og tre minutters rolig aktivitet mellom øktene.

Etter seks måneder målte vi diameteren i koronarområdet der stenten var satt inn. Det viste seg at diameteren var større i pasientpopulasjonen som hadde trent sammenliknet med kontrollgruppen (o,10 mm versus o,39 mm). Treningsgruppen hadde også bedre oksygenopptak enn den andre gruppen, og endotelfunksjonen ble signifikant forbedret. Dessuten var CRP-nivået lavere i treningsgruppen.

Funnene bekrefter verdien av høyintensitetsintervalltrening som effektiv behandlingsform hos koronarsyke pasienter. Studien er liten, og funnene bør bekreftes i en større studie. Trening etter utblokking med stentimplantasjon er per i dag ikke et etablert behandlingstilbud som dekkes av Rikstrygdeverket.

\section{LITTERATUR}

1. Munk PS, Staal EM, Butt N et al. High-intensity interval training may reduce in-stent restenosis following percutaneous coronary intervention with stent implantation: a randomized controlled trial evaluating the relationship to endothelial function and inflammation. Am Heart J 2009; 158: 73441.

Publisert: 11. februar 2010. Tidsskr Nor Legeforen. DOI: 10.4045/tidsskr.10.0041

(C) Tidsskrift for Den norske legeforening 2023. Lastet ned fra tidsskriftet.no 26. april 2023. 